\title{
Genetic Markers and Horticultural Germplasm Management
}

\author{
P.K. Bretting and M.P. Widrlechner \\ U.S. Department of Agriculture, Agricultural Research Service, North Central Regional Plant Introduction Station, \\ Department of Agronomy, Iowa State University, Ames IA 50011
}

This paper is adapted from the text of a seminar of the same title presented as part of the Workshop on Sustainability of Vegetable Breeders' Genetic Resources, 26 July 1993, at the 90th Annual Meeting of the American Society for Horticultural Science. It represents the distillation of a more extensive treatment of genetic markers and germplasm management (Bretting and Widrlechner, 1995).

In this review, we will emphasize the utility and limitations of genetic markers for plant genetic resource or germplasm management, rather than applications of genetic markers to plant breeding or to gene mapping, as these topics have been covered by many thorough recent reviews (Dudley, 1993; Paterson et al., 1991; Tanksley et al., 1989). Plant germplasm management comprises two phases. Germplasm conservation includes acquisition, in which germplasm is safeguarded in situ (by establishing reserves) or ex situ (by assembling collections through exchange or exploration). Germplasm conservation also involves maintenance, protecting germplasm in situ in reserves or storing it ex situ under controlled conditions, propagating it while preserving its original genetic profile with maximum fidelity, monitoring its viability and health in storage or in situ, and maintaining associated passport information and other data. Finally, germplasm conservation also involves characterization, assaying highly heritable morphological and molecular traits for taxonomic, genetic, quality assurance, and other management purposes.

The second phase of germplasm management, encouraging utilization, includes evaluation, assaying agronomically or horticulturally meritorious traits with relatively low heritabilities and high components of environmental variance, e.g., yield, adaptation, and host-plant resistance to certain abiotic/biotic stresses. It also includes genetic enhancement, making particular genes more accessible and usable to breeders by adapting "exotic" germplasm to local environments without losing its essential exotic genetic profile, and/or

Received for publication 31 Mar. 1995. Accepted for publication 8 June 1995. Journal Paper no. J16362 of the Iowa Agriculture and Home Economics Experiment Station, Ames. Project no. 1018. We thank J.S.C. Smith, J. Wendel, and two anonymous reviewers for their valuable critiques of this manuscript. The cost of publishing this paper was defrayed in part by the payment of page charges. Under postal regulations, this paper therefore must be hereby marked advertisement solely to indicate this fact.

HortScience, Vol. 30(7), December 1995 introgressing high-value traits from exotic germplasm into adapted varieties (Duvick, 1990). Simmonds (1993, p. 540) subdivides genetic enhancement into introgressionbackcrossing a few genes controlling desired characters into adapted stocks - and incorporation-"the large-scale development of locally adapted populations good enough to enter the adapted genetic bases of the crops concerned."

Plant germplasm management is vital for providing the plant scientist with sufficient quantities of genetically pure, well-characterized germplasm for research and crop improvement. This germplasm (Brown et al., 1989; Frankel and Soulé, 1981; Holden and Williams, 1984), together with water, air, soil, and proper management practices, comprise the key components of a sustainable agricultural or horticultural system (see Fretz et al., 1993).

\section{ESSENTIAL FEATURES OF GENETIC MARKERS}

What are the essential features of genetic markers? First, they are polymorphic (ideally, highly polymorphic): if they were not, they could not effectively play many of the roles discussed below [see Senior and Heun (1993) for an example and a brief review]. Highly polymorphic markers possess many alleles per locus. Second, genetic markers are highly heritable, i.e., their phenotypic expression is relatively unaffected by environmental variability or by genotype $\times$ environment interactions (Nyquist, 1991). Once their mode(s) of inheritance is understood, they can be assayed without replicated trials and their homology with other markers of the same type (e.g., morphology, isozymes, etc.) can be determined. It is vital to compare only homologous markers, such as alleles of the same locus, for which phenotypic similarities stem from phylogenetic affinity, not from convergent evolution (Doebley and Wendel, 1989).

Third, highly heritable markers are often simply inherited: ideally, they are single Mendelian genes with codominant alleles. Markers with these qualities are often readily interpretable by simple locus/allele models and can be analyzed by a battery of convenient statistics (Nei, 1987; Weir, 1990). Fourth, the various phenotypes of an ideal marker type will be governed by different loci that are well dispersed throughout the genome. Suites of markers that saturate the genome greatly enhance the statistical power of certain key analytical procedures for estimating genetic diversity and divergence (Murray et al., 1988; Smith and Smith, 1992).
Finally, there are various practical considerations to note. Ideally, genetic markers do not differentially affect a plant's fitness, such as some albino mutations do. An ideal marker can be scored rapidly and early in the plant's life cycle (ideally, embryonically); the assays are inexpensive and innocuous, at least to humans, and ideally to all organisms (Murray et al., 1988; Smith, 1989).

\section{GENETIC MARKER TYPES: MORPHOLOGY, KARYOLOGY, AND SECONDARY METABOLITES}

Morphological traits are the oldest and most widely used genetic markers, and they may still be optimal for certain germplasm management applications. Their prime advantages are simplicity and rapid, inexpensive assays, even from herbarium specimens and other dead tissues. For example, in maize (Zea mays L.), the number of kernel rows per ear is highly polymorphic, relatively highly heritable, and consequently has long served as a morphological genetic marker for systematic and evolutionary purposes (Revilla and Tracy, 1995; Sánchez G. et al., 1993). Although this character's genetic basis has been elucidated (Doebley, 1994), few other morphological traits have been similarly characterized, and fewer still possess an ideal genetic marker's other key features-selective neutrality and multiallelic diversity (Smith and Smith, 1992).

Chromosome number and cytomorphological traits also have served as genetic markers, especially in polyploid crop complexes, where they have been important tools for elucidating these plants' systematics and evolution (cf. Simmonds, 1976). The mechanisms for gross karyotypic changes such as translocations, etc. (Dyer, 1979), in general cannot be described by locus/allele models. For example, various loci on the genomes of maize and its wild relatives bear numerous chromosomal knobs of various sizes that, like kernel row count, have long served as genetic markers in maize (see McClintock et al.'s 1981 review) as they are highly heritable and polymorphic. But the genetic mechanism for knob pattern variation is still unknown (Kato Y., 1984; McClintock et al., 1981). Chromosomal morphology has similarly elucidated the evolution and systematic relationships of domesticated and wild Capsicum peppers (Pickersgill, 1971, 1981).

Secondary metabolites, usually anthocyanin and flavonoid pigments (reviewed by Dooner et al., 1991), possess some of the cost/ time efficiency advantages of morphological markers. But they too may not be interpretable by locus/allele models, nor are they necessar- 
ily selectively neutral, e.g., corolla color phenotypes of entomophilous species that encourage positive assortative mating (Leleji, 1973; Widrlechner and Senechal, 1992). Polymorphisms may be scored directly, or the pigments may be fractionated chromatographically, a procedure that may generate toxic wastes, and which is more elaborate and expensive than is simple visual scoring. The genetic basis of pigment polymorphisms is well-known in some crops, e.g., maize (Coe, 1994a; Dooner et al., 1991), Antirrhinum (Dooner et al., 1991), Petunia (Dooner et al., 1991), Pisum (Harker et al., 1990), and amaranths (Kulakow et al., 1985), but not in other crops or in wild plants and wild/weedy crop relatives.

\section{GENETIC MARKER TYPES: PROTEINS}

Seed protein (Gepts, 1990) and isozyme variants (Wendel and Weeden, 1989) that migrate at different rates under electrophoresis have been the most widely employed molecular genetic markers during the last quarter century. Isozymes are generally fractionated by starch gel electrophoresis (Kephart, 1990) in studies of genetic diversity and divergence, whereas seed proteins are generally analyzed via polyacrylamide gels (Cooke, 1984). When conducted according to proper laboratory procedures, protein electrophoretic migration rates are generally highly heritable, and ample polymorphisms are available for many germplasm management purposes (Simpson and Withers, 1986).

Seed proteins have the advantage of being scorable from inviable organs or tissues, and the electrophoretic protocol for bulk protein assays is generally simpler than that for isozymes (Cooke, 1984; Gepts, 1990). In general, however, seed storage protein electrophoretic profiles are rarely interpretable by locus/allele models, and sophisticated computer software may be necessary for analyzing the complicated spot patterns issuing from two-dimensional electrophoresis (BeckstromSternberg, 1989; Celis and Bravo, 1984).

To date, isozymes have been the genetic markers most frequently applied to plant germplasm management (Simpson and Withers, 1986). They are generally (but not always) governed by single Mendelian genes with codominant alleles and, after the appropriate genetic analyses, are interpretable by locus/ allele models (Weeden and Wendel, 1989). They can be assayed from a wide variety of organs and tissues, and analytical procedures are not exceptionally complicated (Murphy et al., 1990; Wendel and Weeden, 1989).

Nevertheless, enzyme-encoding loci do not constitute a random sample of genes, and they are not randomly dispersed throughout the genome. Some isozyme variants are not selectively neutral (DiMichele et al., 1991; Koehn and Hilbish, 1987), and electrophoresis will detect only a portion of the actual variability present in amino acid sequences (Hillis and Moritz, 1990). In studies of genetic diversity and divergence, isozymes with similar enzy- matic activity and electrophoretic migration rates are presumed to be homologous, although this assumption cannot be validated without amino acid sequencing.

\section{GENETIC MARKER TYPES: DNA}

Various DNA polymorphisms are the most highly heritable of all genetic markers, and, in plants, they can be assayed from three distinct genomes-nuclear, chloroplast, and mitochondrial-each of which evolves according to different modes and tempos (Wolfe et al., 1987). It is also likely that many, if not most, polymorphisms in noncoding sequences are selectively neutral (Kimura, 1983; Nei, 1987).

Restriction fragment length polymorphism (RFLP) analysis involves digesting the subject genome with cleaving restriction enzymes, fractionating the fragments electrophoretically, and then preferentially visualizing fragments containing particular homologous sequences by hybridizing them to a specific DNA probe (DeVerna and Alpert, 1990; Dowling et al., 1990; Walton, 1990). RFLPs are codominantly inherited and relatively high in allelic diversity (Helentjaris and Burr, 1989). High confidence can be placed in the homology of fragments with identical electrophoretic mobilities, provided the probe has been mapped to a particular locus (Smith and Smith, 1992). Currently, RFLP analysis is relatively laborintensive, and involves expensive and sometimes radioactive/toxic reagents (Bernatzky and Tanksley, 1989; Murray et al., 1988).

DNA amplification technologies (Erlich et al., 1991; Mullis et al., 1986) may require little tissue for assays (e.g., only half a caryopsis, Chuwongse et al., 1993), are more amenable to automation than is RFLP analysis, and do not involve the labor-intensive steps of Southern blotting and probing. Nevertheless, for certain applications, amplification technology may be as or more expensive than RFLP analyses (Kwoh and Kwoh, 1990; Ragot and Hoisington, 1990). Amplification procedures all involve amplifying, or propagating, millions of copies of particular gene sequences via the polymerase chain reaction (PCR) or related amplification reactions (Mullis et al., 1986). Relatively short DNA oligomers (generally $<25$ bp long), often called "primers," bracket the DNA interval that is the target sequence for amplification. When the amplified sequence lengths vary, they migrate differentially when electrophoresed.

Several related, but slightly different, methods termed "randomly amplified polymorphic DNA" or "RAPD" (Williams et al., 1990), "arbitrarily-primed PCR" or "AP-PCR" (Welsh and McClelland, 1990), "DNA amplification fingerprinting" or "DAF" (CaetanoAnollés et al., 1991), and "amplified fragment length polymorphism" or "AFLP” (Zabeau and Vos, 1993), use single, <12-bp primers with arbitrary nucleotide sequences, relative to the target DNA sequence. Ideally, these arbitrary primers yield at least several, but not too many, marker bands that generally are inherited as dominant alleles, whereas fragment absence generally is recessive. Allelic frequencies of these dominant markers may be calculated via maximum likelihood methods (Edwards, 1992). Nevertheless, the homologies of these bands may be quite uncertain, so arbitrary primer methods are most useful when analyzing closely related germplasm (Smith, 1992).

As with Southern blotting/probe-hybridization methods, amplification protocols also can be applied to specific genetic loci, e.g., tandemly repeated nucleotide sequences, that have substantial utility as genetic markers (Thomas and Scott, 1994). Electrophoretic fractionation reveals polymorphisms in these sequences, which are termed variable-number tandem repeats ("VNTRs"), "minisatellites" (10 to $150 \mathrm{bp}$ ), or "microsatellites" (1 to $4 \mathrm{bp}$ ) according to the length of the repeated sequence (Jeffreys et al., 1985; Litt and Luty, 1989; Nakamura et al., 1987). The DNA products resulting from amplification of these "hypervariable" loci are typically highly polymorphic, inherited as codominant alleles of a single locus, and, unlike many similarly sized fragments produced by arbitrary primer methods, are assumed to represent variants of homologous loci (Senior and Heun, 1993). Their ubiquity in nuclear genomes (Wang et al., 1994) and relatively high allelic diversity may make them valuable genetic markers for plant genetic resource management (Akkaya et al., 1992).

\section{ANALYTICAL APPROACHES}

Although they are suboptimal for many plant genetic resource management applications, approaches for analyzing quantitative traits, many of which are morphological, will be discussed briefly. These traits may be assayed in replicated trials and the resultant data examined by analyses of variance to estimate the genotypic contribution to the phenotype (Goodman and Paterniani, 1969; Sánchez G. et al., 1993). Multivariate approaches for estimating trait independence or correlation are described by Sánchez G. et al. (1993). Highly correlated traits yield less independent information than do uncorrelated traits, and they can complicate certain statistical techniques (Dunn and Everitt, 1982; Morrison, 1976; Sneath and Sokal, 1973). Finally, because of the complexity of certain morphological traits (e.g., shapes), computerized data acquisition, imaging, and analysis may be necessary (Keefe and Draper, 1988; Mincione et al., 1994).

The genetic markers most useful to plant genetic resource management have phenotypes that are expressed as discrete classes, interpretable by locus-allele models, and tractable to binomial or multinomial statistical analysis (Nei, 1987; Weir, 1990). Allelism tests (Coe, 1994b) of marker variants should be conducted so that allelic frequencies and their variances can be calculated.

\section{MEASURES OF GENETIC DIVERSITY AND STRUCTURE}

Common indices for allelic diversity include mean alleles per locus $(A)$, percentage of 
polymorphic loci $(P)$, and various gene diversity statistics (e.g., $H_{\mathrm{t}}, H_{\mathrm{s}}$ ) developed by Nei $(1973,1987)$. For all these indices, both the number of individuals and number of loci assayed are critical for estimating their true values.

The statistic $A$ measures allelic "richness." Its value strongly depends on sample size, because small samples are less likely to include rare alleles. The statistic $P$ is also affected by sample size and is relatively strongly dependent on the number of loci assayed, and its measure may be subject to large statistical sampling error. Of course, polymorphism is defined arbitrarily by the frequency of the predominant allele and the sample size (Nei, 1987; Weir, 1990).

When the germplasm under study is in Hardy-Weinberg equilibrium, the frequency of heterozygotes can serve as an index of genetic diversity. But heterozygote frequency cannot serve in this capacity for haploid, polyploid, or primarily autogamous plants (Nei, 1973). Consequently, Nei's genetic diversity statistic (Nei, 1973), derived from the sampling properties of alleles, is superior to heterozygote frequency and other statistics as a measure of genetic diversity. It is not strongly affected by sample size (when 20 or more loci are screened) nor ploidy levels. But, its value cannot surpass 1 ; it is relatively insensitive to changes in allelic frequencies as they approach 1 (Brown and Weir, 1983); and it strongly depends on the frequencies of the two most common alleles (Simon and Archie, 1985).

Allogamous germplasm can be tested for Hardy-Weinberg equilibrium by genetic markers interpretable by locus/allele models (Frankel and Galun, 1977; Hernández and Weir, 1989; Weir, 1990). If, like inbreeding or clonal germplasm, allogamous germplasm is not in Hardy-Weinberg equilibrium, its populations will conform to a different type of genetic structure. Populational structure can be quantified from allelic data via Cockerham's variance component approach based on coancestries (Cockerham, 1973; Huff et al., 1993), Wright's $F$ statistics (Wright, 1978), or most popularly, via Nei's gene diversity statistics (Nei, 1973). Error terms can be calculated for all of these measures (Nei, 1987; Weir, 1990).

\section{MEASURES OF GENETIC PROXIMITY}

Finally, measures of genetic proximity or identity can be derived from genetic marker data. For quantitative data or mixtures of quantitative and qualitative data, Gower's proximity coefficient is recommended (Gower, 1971). For RFLP data uninterpretable by locus-allele models, the statistic $d$ of Nei and Li (1979) is frequently calculated as a proximity measure (Nei and Tajima, 1983), whereas Clark and Lanigan (1993) have derived an analogous proximity measure for data resulting from RAPD analysis.

For locus-allele data, Nei's identity $(I)$, Nei's distance (D) (Nei, 1972, 1987), Rogers' distance, or a modified Rogers' distance
(Rogers, 1972; Wright, 1978) are commonly used to measure genetic proximity. Although the significance of differences among $D$ s and among other proximity measures can be tested statistically (Nei, 1987), it rarely is done, because calculating variances for these parameters, which are ratios of quadratic functions, is quite complicated (Nei, 1987; Weir, 1990). Weir (1990) recommended numerical resampling techniques, such as bootstrapping (Efron and Tibshirani, 1991), for significance testing [see Smith et al. (1991) for an example].

Unless a systematic-evolutionary study is required, phenetic techniques based on overall genetic similarities are often used for germplasm management applications. In phenetics, or numerical taxonomy, character variability is examined without weighting the traits a priori, and without reference to the evolutionary events responsible for phylogenetic or genetic divergence (Duncan and Baum, 1981). A phenetic approach is most appropriate with taxa (e.g., crops and their wild/weedy relatives) that have diverged relatively recently. In recently diverged taxa, overall genetic affinity may be still strongly congruent with the degree of evolutionary divergence (Duncan and Baum, 1981).

The raw marker data or derived proximity measures can be analyzed phenetically by multivariate ordination methods, such as principal components or discriminant analyses, or by cluster analysis (Baum et al., 1984; Duncan and Baum, 1981; Dunn and Everitt, 1982; Manly, 1986; Morrison, 1976; Sneath and Sokal, 1973; Sokal, 1986). Ideally, these two multivariate techniques are applied together, because their strengths are complementary (Dunn and Everitt, 1982; Sneath and Sokal, 1973; Sokal, 1986).

In cluster analysis, taxa, germplasm collections, genetic markers, etc., are arranged in a hierarchy (called a "phenogram" or "dendrogram") by an agglomerative algorithm according to the structure of a matrix of pairwise genetic proximity measures. The hierarchies emerging from cluster analyses are highly dependent on the proximity measure and clustering algorithm used (Smith and Smith, 1992; Sneath and Sokal, 1973; Sokal, 1986).

In ordination techniques, the multidimensional variability in a pairwise, intertaxon or intermarker proximity matrix, or in a variance-covariance or correlation matrix, is depicted in one to several dimensions through eigenstructure analysis. Ordination is best suited to revealing interactions and associations among taxa, germplasm accessions, etc., which are described by continuous, quantitative data. Principal component, principal coordinate, and linear discriminant analyses are the ordination techniques most relevant for germplasm management applications (James and McCulloch, 1990; Sneath and Sokal, 1973; Sokal, 1986).

Supraspecific systematic and genetic relationships are currently often elucidated by cladistic methods (Duncan and Stuessy, 1984; Swofford and Olsen, 1990). In general, the genetic resource manager will find standard phenetic approaches appropriate and suffi- cient for quantitatively analyzing marker data for genetic diversity assessment.

\section{GENETIC MARKERS AND PLANT GENETIC RESOURCE MANAGEMENT}

The remainder of this paper presents specific examples, emphasizing horticultural crops, of how genetic markers can contribute to managing germplasm ex situ. The optimal genetic marker for specific managerial purposes is determined partly by the germplasm's genetic diversity profile. Plant germplasm can be genetically homozygous and homogeneous (e.g., an inbred line), homozygous and heterogeneous (e.g., synthetic mixtures or traditional varieties of inbreeding crops), heterozygous and homogeneous (e.g., many clonally propagated varieties derived from allogamous species), or heterozygous and heterogeneous (e.g., allogamous land races). In general, germplasm with heterozygous and heterogeneous genetic profiles are the most difficult and expensive to manage; hence, their managerial programs might benefit the most from the availability of genetic marker data.

\section{GENETIC MARKERS AND OPTIMAL GERMPLASM ACQUISITION AND SAMPLING}

The initial step in genetic resource management programs involves acquiring germplasm by collecting propagules during plant exploration or through exchange with other institutions or collectors. Genetic markers can aid germplasm acquisition by helping to identify "gaps" and redundancies in collections, and by helping to develop optimal sampling strategies for field collecting. For example, calyx shape is strongly associated with ploidy in sweetpotato [Ipomoea batatas (L.) Lam.] (Bohac et al., 1993); consequently, Austin et al. (1993) could discriminate $4 x$ (the focus of their plant exploration) from $6 x$ sweetpotatoes efficiently in the field by their diagnostic calyx morphology.

A simple but perhaps effective approach for optimizing sampling strategies involves graphing the amount of genetic diversity (as determined by genetic markers) in a sample against the number of individuals, populations, or taxa constituting the sample. Optimal sample sizes, relative to total genetic diversity, are identified according to the slope(s), inflection point(s), or both, of the functional relationship between these variables. In tomato and its wild or weedy relatives (Lycopersicon spp.), species-specific functional relationships between sample size and amount of genetic diversity indicated to Miller and Tanksley (1990) that populations of a selfincompatible Lycopersicon species were 20 times more likely to include a novel RFLP fragment than were populations of a selfcompatible species. Accordingly, Miller and Tanksley recommended that relatively more accessions per self-incompatible species than per self-compatible species should be included in germplasm banks. 
A recent RFLP genetic marker analysis of chloroplast DNA from Zea perennis (Hitchc.) Reeves and Mangelsdorf demonstrated that some populations of this species have a plastid haplotype that was otherwise completely unknown in other teosintes, in maize, or in Tripsacum (Doebley, 1989). Collecting more $Z$. perennis populations from that particular accession's provenance thus became a priority, and a search for other highly divergent "missing teosintes" that may fill a gap in ex situ collections has been proposed.

\section{GENETIC MARKERS AND GERMPLASM MAINTENANCE}

After germplasm is acquired, it must be maintained. Germplasm maintenance, one of the most important and costly components of managing germplasm ex situ, involves keeping accessions true-to-type while increasing the number of propagules, through plant propagation, for distribution (Holden and Williams, 1984; Plucknett et al., 1987; Soulé and Frankel, 1981). Genetic markers may help increase the efficacy and efficiency of germplasm maintenance in several ways. Genetic markers have demonstrated that genotypic frequencies in a homozygous, heterogeneous germplasm mixture may shift dramatically after just a few regeneration cycles through the differential viability of certain genotypes. For example, Roos (1984a, 1984b) showed how the frequencies of various Phaseolus cultivars (identifiable by seedcoat color markers) in a mixed accession shifted drastically through time after simulated regeneration cycles.

Isozyme genetic markers are commonplace quality assurance tools for producing commercial, elite germplasm that is very pure, i.e., true-to-type [see Arús (1983) for a review]. Comparing a subsample of each lot with a genotypic standard reveals off-type plants, such as self-pollinated plants in a hybrid seed lot of tomato (Lycopersicon esculentum Mill.) (Tanksley and Jones, 1981) or of Brassica (Arús, 1983; Surrs, 1986). Various DNA fingerprinting techniques may prove particularly valuable for identifying specific clones and monitoring their trueness-to-type through regeneration cycles (Kaemmer et al., 1992; Thomas et al., 1993).

Pollen-sterility genes served as genetic markers in a test of caged honeybees' ability to forage for pollen outside of screened cages, yet pollinate the sunflowers (Helianthus annuus L.) inside the cages with pollen only from other caged sunflowers, not from pollen from plants outside the cage. In this case, all the caged sunflowers were cytoplasmic male-sterile, so that any achenes set must have resulted from external pollen sources. This pollen-sterile genetic marker demonstrated conclusively that honeybees carried no viable pollen into the cages (Wilson, 1989).

Regardless of whether germplasm is maintained in vivo (seeds, clones) or in vitro (calli, gene sequences), it must be stored under conditions that maximize longevity and should be screened regularly for vigor and health. Al- though not truly genetic markers, enzyme linked immunosorbent assays (protein antibodies raised to particular pathogen antigens linked to a color indicator), or nucleic acid probes that hybridize to pathogen-specific nucleic acid sequences, help maintain germplasm health (Catello et al., 1988; Clark, 1981). Further, isozyme (Recchio-Demmin et al., 1990) and morphological (Klein et al., 1990) markers have documented loss of genetic diversity in Pisum and Phaseolus germplasm as a consequence of managerial efforts to eliminate plant viruses.

\section{GENETIC MARKERS AND GERMPLASM CHARACTERIZATION}

Germplasm that is most valuable to scientific research and crop improvement has been characterized genetically; genetic markers serve as the foundation for such characterization. One of the most important roles for genetic markers is determining systematic relationships - the critical framework for organizing genetic diversity/divergence data (Crawford, 1990; Stuessy, 1990). Misunderstanding systematic relationships had left some germplasm, e.g., Cucurbita okeechobeensis (Small) L.H. Bailey, endangered in situ and without legal protection. Recent isozyme marker data analyzed by multivariate statistical methods analyses may help win deserved protection for this cucurbit (Walters and Decker-Walters, 1993).

Genetic markers also help correctly identify germplasm accessions. For example, Bohac et al. (1993) determined from morphological markers (calyx and corolla traits) that wild $4 x$ Ipomoea germplasm accessions maintained ex situ were not I. trifida (Kunth) G. Don f., but rather a $4 x$ race of the generally $6 x$ sweetpotato [I. $\operatorname{batatas}(\mathrm{L}$.) Lam.]. This taxonomic realignment will likely change how these germplasm accessions will be managed and used in the future.

Genetic marker data also may reveal the genetic profiles and populational genetic structure of newly acquired germplasm as a prelude to ex situ management per se. This initial "genetic assessment," advocated by Brown and Clegg (1983) more than a decade ago, is still not routinely conducted before initiating germplasm maintenance or utilization. One notable exception to this generality is an integrated isozyme, pigment, morphological, and agronomic marker assessment (Hamon and van Sloten, 1989) that yielded recommendations for optimally managing West African okra germplasm [Abelmoschus esculentus (L.) Moench]. The heritabilities for the various genetic markers were not reported, but the intercharacter associations identified by cluster analyses suggested that the number of markers assayed routinely could be reduced. Accordingly, field experiment designs were modified during the course of the managerial program by the results of isozyme marker analysis, which, at the seedling stage, could discriminate okra cultivars from one another, and from their wild relatives (Hamon and van Sloten,1989).

\section{GENETIC MARKERS AND CORE SUBSETS}

Establishing core subsets of ex situ collections is currently of considerable interest to many plant genetic resource managers. At its simplest, delimiting core subsets involves estimating, by statistical genetic theory, the probability that a selected (sometimes randomly, sometimes via particular sampling criteria) sample of accessions will include a given proportion of alleles that occur in the entire germplasm collection at a given frequency (Brown, 1989a, 1989b). Accordingly, theoretical calculations (Brown, 1989a, 1989b) suggested that a core subset of $\approx 10 \%$ of the accessions in a collection of 10,000 or more accessions would probably ( $95 \%$ confidence level) include most (70\% or more) of the alleles that are actually widespread throughout the collection.

We suggest that core subset formation should not proceed until the germplasm in question undergoes thorough characterization with two or more types of genetic markers. Schoen and Brown's (1993) recent computer simulations indicated that genetic markerassisted core subset formation retained allelic diversity and richness more effectively than did other methods. Nevertheless, to date, most attempts to assemble and test core subsets have been guided by provenance (ecogeographical) information and the preceding statistical genetic theory, whereas fewer have incorporated genetic marker data (Brown, 1989b)

Erskine and Muehlbauer (1991) used 17 isozyme marker loci, another putative isozyme marker, and three genes encoding pigments to test the utility of a core subset comprising a random sample of $\approx 10 \%$ of a lentil (Lens culinaris Medikus) germplasm collection. All but two of the preceding markers were unlinked, but multilocus genotypic associations were pervasive, diverse, and statistically very strong throughout the collection. These highly heritable markers suggested that the proportion of the total collection's genetic diversity included in the "random" core subset was not significantly different statistically from the proportions captured by two other core subsets that were assembled via stratified sampling according to the accessions' geographical provenances.

Knowledge of patterns of genetic diversity in germplasm collections, provided by genetic markers, can aid in assembling "test arrays," ad hoc subsets of germplasm collections designed for evaluation programs, and, hence, for facilitating germplasm utilization rather than conservation. [See Beuselinck and Steiner (1992) for the "standard range collection" approach to assembling test arrays]. If these arrays can be circumscribed to contain maximal genetic diversity with minimal redundancy, then they may enhance the efficacy and efficiency of germplasm utilization. Kresovich et al.'s (1992) analysis of germplasm accessions of Brassica oleracea L. suggests that genetic markers can indeed play a role in assembling optimal test arrays. 


\section{GENETIC MARKERS AND GERMPLASM EVALUATIONS}

Germplasm utilization is facilitated when germplasm is evaluated for the converse of ideal genetic markers-i.e., traits such as yield and adaptation. Currently, crop improvement programs are trying to exploit associations (generally physical linkages) among genes for agronomically or horticulturally important traits and molecular genetic markers. Genetic markers may help optimize germplasm utilization strategies by identifying novel (relative to the germplasm in common use) alleles of valuable polygenic traits with relatively low heritabilities (Bubeck et al., 1993; Knott and Dvorak, 1976; Soller and Beckmann, 1988; Stalker, 1980), and by helping incorporate these sometimes latent traits into breeding populations (Bernatzky and Tanksley, 1989; Soller and Beckmann, 1988).

Genetic marker-assisted germplasm evaluations or manipulations can be placed into one of several broad classes. The first category involves genetic markers highly associated with relatively high-value plant products (e.g., agronomic-horticultural, industrial, or medicinal). For example, by selecting isozyme or immunological markers with higher heritabilities, or with a simpler genetic control relative to valuable traits with which they were linked, Bliss and coworkers (Bliss, 1990) introgressed genes encoding higher protein content and accelerated rates of $\mathrm{N}_{2}$ fixation from wild bean relatives into domesticated Phaseolus vulgaris $\mathrm{L}$.

In the second category, crop improvement efforts exploit the association or linkage of genetic markers with genes for host-plant resistance to abiotic or biotic stresses [e.g., see Martin et al. (1991) and Nance et al.'s (1992) review for forest trees]. A classic example of exploiting such linkages in a horticultural crop is the discovery that, in tomato and its wild relatives, host-plant resistance to nematode infestation is highly correlated with an acid phosphatase allozyme (Rick and Fobes, 1974). Since 1974, tomato germplasm has often been routinely screened for the isozyme marker, rather than assayed directly for nematode resistance, because the isozyme analyses are more effective and efficient than are the direct assays (DeVerna and Alpert, 1990)

In the third and last category, genetic markers can be crucial for screening germplasm with protracted juvenile periods (i.e., tree crops or ornamental perennials) early in their life cycle (ideally, as seedlings) for horticulturally or silviculturally meritorious traits. For example, in Malus (apples and wild relatives), an isozyme marker tightly linked to the $S$ gene(s) governing incompatibility can greatly improve the efficiency of apple breeding programs (Manganaris and Alston, 1987). Furthermore, under certain conditions, nucellar seedlings in Citrus spp. can be distinguished isozymatically from those resulting from sexual reproduction (Torres et al., 1982), a technique that facilitates efficient clonal propagation of Citrus spp.

\section{GENETIC MARKERS AND GENETIC ENHANCEMENT}

Finally, genetic markers may facilitate genetic enhancement, sometimes termed prebreeding, by adapting alien material to local conditions without losing its essential genetic contributions, or by introgressing genes for yield, for high-value traits, or both into already adapted material (Duvick, 1990). The latter procedure is commonplace in contemporary plant breeding, whereas the former process, termed "base-broadening" by Simmonds (1993) because it widens the locally adapted genetic base for crops, is less frequently conducted.

To date, the most important contribution of genetic markers to "base-broadening" programs is a posteriori demonstration that such efforts can produce locally adapted germplasm that retains substantial proportions of the unadapted germplasm's genome. For example, diagnostic isozyme markers demonstrated that genes from unadapted, tropical germplasm persisted in tropical-temperate sweet corn germplasm (Rubino and Davis, 1991) and in tropical dent corn-temperate Corn Belt Dent germplasm (Bretting et al., unpublished). Also, a combination of RAPD and RFLP markers indicated that plant breeding programs in tomato have broadened the genetic base of modern cultivars, relative to older varieties (Williams and St. Clair, 1993).

Persistence of genetic markers diagnostic for the unadapted germplasm (and, presumably, that are linked to genes of agronomic value) indicates that, after several generations of random-mating, natural selection, and relatively "weak" agronomic selection, substantial genomic segments from unadapted germplasm can be preserved, at least partially, during genetic enhancement for local adaptation. Although this research represents an $a$ posteriori view, it does demonstrate the potential utility of genetic markers in efforts to minimize genetic vulnerability by maximizing genetic diversity.

Genetic markers are currently more commonly used to introgress specific high-value traits, mentioned earlier, into adapted, elite germplasm than to facilitate base-broadening programs. For example, isozyme, RFLP, and morphological markers diagnostic for chromosomes of tomato's wild/weedy relatives aided introgression of chromosomal segments from wild species into elite tomato germplasm (DeVerna et al., 1987, 1990), which increased the yield of horticulturally valuable products (Rick, 1988).

\section{CONCLUSIONS}

What conclusions have emerged from this assessment of the role of genetic markers in plant germplasm management? First, the optimal genetic marker type for a particular managerial task is determined by the kind of germplasm (wild species, landrace, or elite cultivar) to be managed and its genetic profile (homozygous-homogeneous, heterozygousheterogeneous, etc.). Morphological or pig- ment markers that are oligogenic and highly heritable may suffice for determining whether pollination control is actually effectively preventing gene flow; in contrast, genetic diversity assessment ideally employs a broad suite of molecular markers dispersed throughout the genome (Kresovich and McFerson, 1992). The utility of a genetic marker is always relative, and is determined by particular managerial applications and by the specific natural history and genetic architecture of the germplasm.

Second, isozymes have long been the workhorse genetic markers in plant germplasm management (Tanksley and Orton, 1983a, 1983b), and they will continue to be so for the near future, at least for certain applications. They are still the most cost-effective means of securing a variety -10 to 20 loci- of codominant, Mendelian genetic markers.

Third, the various DNA amplification methods mentioned earlier are the most promising molecular markers for the future (Beckmann and Soller, 1990). This technology is evolving so rapidly that specific prophesies will not be hazarded. But, hypervariable loci with relatively many codominant alleles have substantial advantages over RFLPs - in terms of cost efficiency and the potential for automating procedures - and over amplification reactions with single, arbitrarily chosen primers (RAPDs; Williams et al., 1993), where there are relatively few alleles per locus, and the alleles are usually dominant (Morgante and Olivieri, 1993).

Fourth, although we have made only passing reference to computers, we must note that without computer hardware and software for data management, genetic markers would be much less valuable for germplasm characterization and evaluation. Advances in computerized genetic data acquisition (e.g., scanning), database management, and statistical analyses are vital for genetic resource management in the future (Keefe and Draper, 1988; Mincione et al., 1994).

Finally, as Goodman and Stuber (1980, p. 26) stated in their assessment of the role of isozyme analyses in plant breeding: "Rarely is the currently popular fad the panacea that its most exhortant promoters imply": an insight more generally applicable than these authors may have envisioned. For, although genetic markers are very valuable tools, even the most powerful markers and/or computer-assisted analyses cannot substitute for curatorial expertise, i.e., managerial experience, prudent judgment, and keen knowledge of plant germplasm's natural history or history of human manipulation.

\section{Literature Cited}

Akkaya, M.S., A.A. Bhagwat, and P.B. Cregan. 1992. Length polymorphisms of simple sequence repeat DNA in soybean. Genetics 132:11311139.

Arús, P. 1983. Seed purity in commercial seed lots, p. 415-423. In: S.D. Tanksley and T.J. Orton (eds.). Isozymes in plant genetics and breeding. Developments in plant genetics and breeding. vol. 1A. Elsevier, Amsterdam, The Netherlands. 
Austin, D.F., R.L. Jarret, C. Tapia, and F. de la Puente. 1993. Collecting tetraploid I. batatas (L.) Lam. in Ecuador. FAO/IBPGR Plant Genet. Resources Nwsl. 91/92:33-35.

Baum, B.R., T. Duncan, and R.B. Phillips. 1984. A bibliography of numerical phenetic studies in systematic botany. Ann. Missouri Bot. Garden 71:1044-1060.

Beckmann, J.S. and M. Soller. 1990. Toward a unified approach to genetic mapping of eukaryotes based on sequence tagged microsatellite sites. Biotechnology 8:930-932.

Beckstrom-Sternberg, S. 1989. Two-dimensional gel electrophoresis as a taxonomic tool: Evidence from the Centrospermae. Biochem. Syst. Ecol. 17:573-582.

Bernatzky, R. and S.D. Tanksley. 1989. Restriction fragments as molecular markers for germplasm evaluation and utilization, p. 353-362.In: A.H.D. Brown, O. Frankel, D.R. Marshall, and J.T. Williams (eds.). The use of plant genetic resources. Cambridge Univ. Press, Cambridge, U.K.

Beuselinck, P.R. and J.J. Steiner. 1992. A proposed framework for identifying, quantifying, and utilizing plant germplasm resources. Field Crops Res. 29:261-272.

Bliss, F.A. 1990. Utilization of genetic resources for crop improvement: The common bean, p. 317 333. In: A.H.D. Brown, M.T. Clegg, A.L. Kahler, and B.S. Weir (eds.). Plant population genetics, breeding, and genetic resources. Sinauer Assoc., Sunderland, Mass.

Bohac, J.R., D.F. Austin, and A. Jones. 1993. Discovery of wild tetraploid sweetpotatoes. Econ. Bot. 47:193-201.

Bretting, P.K. and M.P. Widrlechner. 1995. Genetic markers and plant genetic resource management. Plant Breed. Rev. 13:11-86.

Brown, A.H.D. 1989a. The case for core collections, p. 136-156. In: A.H.D. Brown, O. Frankel, D. Marshall, and J.T. Williams (eds.). The use of plant genetic resources. Cambridge Univ. Press, Cambridge, U.K.

Brown, A.H.D. 1989b. Core collections: A practical approach to genetic resources management. Genome 31:818-824.

Brown, A.H.D. and M.T. Clegg. 1983. Isozyme assessment of plant genetic resources, p. 285295. In: M.C. Battazi, J.G. Scandalios, and G.S.Whitt (eds.). Isozymes: Current topics in biological and medical research. vol. 11. Medical and other applications. A.R. Liss, New York.

Brown, A.H.D., O.H. Frankel, D.R. Marshall, and J.T. Williams. 1989. The use of plant genetic resources. Cambridge Univ. Press, Cambridge, U.K.

Brown, A.H.D. and B.S. Weir. 1983. Measuring genetic variability in plant populations, p. 219240. In: S.D. Tanksley and T.J. Orton (eds.). Isozymes in plant genetics and breeding. Developments in plant genetics and breeding. vol. 1A. Elsevier, Amsterdam, The Netherlands.

Bubeck, D.M., M.M. Goodman, W.D. Beavis, and D. Grant. 1993. Quantitative trait loci controlling resistance to gray leaf spot in maize. Crop Sci. 33:838-847.

Caetano-Anollés, G., B. Bassam, and P.J. Gresshoff. 1991. DNA amplification fingerprinting using very short arbitrary oligonucleotide primers. Biotechnology 9:553-557.

Catello, J.D., M.A. Ferris, and C.M. Craft. 1988 Applications of enzyme-linked immunosorbent assays in plant pathology, p. 348-362. In: F.A. Valentine (ed.). Forest and crop biotechnology: Progress and prospects. Springer Verlag, New York.

Celis, J.E. and R. Bravo. 1984. Two-dimensional gel electrophoresis of proteins: Methods and applications. Academic, New York.

Chuwongse, J., G.B. Martin, and S.D. Tanksley. 1993. Pre-germination screening using PCR amplification of half-seeds. Theor. Appl. Genet. 86:694-698.

Clark, A.G. and C.M.S. Lanigan. 1993. Prospects for estimating nucleotide divergence with RAPDs. Mol. Biol. Evol. 10:1096-1111.

Clark, M.F. 1981. Immunosorbent assays in plant pathology. Annu. Rev. Phytopathol. 19:83-106.

Cockerham, C.C. 1973. Analyses of gene frequencies. Genetics 74:679-700.

Coe, E. 1994a. Anthocyanin genetics, p. 279-281. In: M. Freeling and V. Walbot (eds.). The maize handbook. Springer Verlag, New York.

Coe, E. 1994b. Genetic experiments and testing, p. 189-197. In: M. Freeling and V. Walbot (eds.). The maize handbook. Springer Verlag, New York.

Cooke, R.J. 1984. The characterization and identification of crop cultivars by electrophoresis. Electrophoresis 5:59-72.

Crawford, D. 1990. Plant molecular systematics: Macromolecular approaches. Wiley, New York.

DeVerna, J.W. and K.B. Alpert. 1990. RFLP technology, p. 247-250. In: A.B. Bennett and S.D. O'Neil (eds.). Horticultural biotechnology: Proc. Hort. Biotechnol. Symp. Univ. of California, Davis, 21-23 Aug. 1989. Wiley-Liss, New York.

DeVerna, J.W., R.T. Chetelat, C.M. Rick, and M.A. Stevens. 1987. Introgression of Solanum lycopersicoides germplasm, p. 27-36. In: D.J. Nevins and R.A. Jones (eds.). Tomato biotechnology: Proceedings of a seminar held at the Univ. of California, Davis, 20-22 Aug. 1986. Plant Biology, vol. 4. Alan R. Liss, New York.

DiMichele, L., K.T. Paynter, and D.A. Powers. 1991. Evidence of lactate dehydrogenase-B allozyme effects in the teleost, Fundulus heteroclitus. Science 253:898-900.

Doebley, J.F. 1989. Molecular evidence for a missing wild relative of maize and the introgression of its chloroplast genome into Zea perennis. Evolution 43:1555-1559.

Doebley, J.F. 1994. Genetics and the morphological evolution of maize, p. 66-77. In: M. Freeling and V. Walbot (eds.). The maize handbook. Springer Verlag, New York.

Doebley, J.F. and J.F. Wendel. 1989. Application of RFLPs to plant systematics, p. 57-68. In: T. Helentjaris and B. Burr (eds.). Development and application of molecular markers to problems in plant genetics. (Current communications in molecular biology). Cold Spring Harbor Lab., Cold Spring Harbor, N.Y

Dooner, H.K., T.P. Robbins, and R.A. Jorgensen. 1991. Genetic and developmental control of anthocyanin biosynthesis. Annu. Rev. Genet. 25:173-199.

Dowling, T.E., C. Moritz, and J.D. Palmer. 1990. Nucleic acids II: Restriction site analysis, p. 250-317. In: D.M. Hillis and C. Moritz (eds.). Molecular systematics. Sinauer Assoc., Sunderland, Mass.

Dudley, J.W. 1993. Molecular markers in plant improvement: Manipulation of genes affecting quality traits. Crop Sci. 33:660-668.

Duncan, T. and B.R. Baum. 1981. Numerical phenetics: Its uses in botanical systematics. Annu. Rev. Ecol. Syst. 12:387-404.

Duncan, T. and T.F. Stuessy. 1984. Cladistics: Perspectives on the reconstruction of natural history. Columbia Univ. Press, New York.

Dunn, G. and B.S. Everitt. 1982. An introduction to mathematical taxonomy. Cambridge studies in mathematical biology. vol. 5. Cambridge Univ. Press, Cambridge, U.K.

Duvick, D.N. 1990. Genetic enhancement and plant breeding, p. 90-96. In: J. Janick and J. Simon (eds.). Advances in new crops: Proceedings of the first national symposium on new crops: Research, development, economics. Timber Press, Portland, Ore.

Dyer, A.F. 1979. Investigating chromosomes. Wiley, New York.

Edwards, A.W.F. 1992. Likelihood. (expanded ed.). The Johns Hopkins Univ. Press, Baltimore.

Efron, B. and R. Tibshirani. 1991. Statistical data analysis in the computer age. Science 253:390395.

Erlich, H.A., D. Gelfand, and J.J. Sninsky. 1991. Recent advances in the polymerase chain reaction. Science 252:1643-1651.

Erskine, W. and F.J. Muehlbauer. 1991. Allozyme and morphological variability: Outcrossing rate and core collection formation in lentil germplasm. Theor. Appl. Genet. 83:119-125.

Frankel, O. and M. Soulé. 1981. Conservation and evolution. Cambridge Univ. Press, Cambridge, U.K

Frankel, R. and E. Galun. 1977. Pollination mechanisms, reproduction, and plant breeding. Springer Verlag, Berlin.

Fretz, T.A., D.R. Keeney, and S.B. Sterrett. 1993. Sustainability: Defining the new paradigm. HortTechnology 3:118-126.

Gepts, P. 1990. Genetic diversity of seed storage proteins in plants, p. 64-82. In: A.H.D. Brown, M.T. Clegg, A.L. Kahler, and B.S. Weir (eds.).Plant population genetics, breeding, and genetic resources. Sinauer Assoc., Sunderland, Mass.

Goodman, M.M. and E. Paterniani. 1969. The races of maize: III. Choices of appropriate characters for racial classification. Econ. Bot. 23:265-273.

Goodman, M.M. and C.W. Stuber. 1980. Genetic identification of lines and crosses using isoenzyme electrophoresis. Proc. Annu. Corn \& Sorghum Res. Conf. 35:10-31.

Gower, J. 1971. A general coefficient of similarity and some of its properties. Biometrics 27:857874.

Hamon, S. and D.H. van Sloten. 1989. Characterization and evaluation of okra, p. 173-196. In: A.H.D. Brown, O. Frankel, D.R. Marshall, and J.T. Williams (eds.). The use of plant genetic resources. Cambridge Univ. Press, Cambridge, U.K.

Harker, C.L., T.H.N. Ellis, and E.S. Coen. 1990. Identification and genetic regulation of the chalcone synthase multigene family in pea. Plant Cell 2:184-193.

Helentjaris, T. and B. Burr (eds.). 1989. Development and application of molecular markers to problems in plant genetics. (Current communications in molecular biology). Cold Spring Harbor Lab., Cold Spring Harbor, N.Y.

Hernández, J.L. and B.S. Weir. 1989. A disequilibrium coefficient approach to HardyWeinberg testing. Biometrics 45:53-70.

Hillis, D.M. and C. Moritz (eds.). 1990. Molecular systematics. Sinauer Assoc., Sunderland, Mass.

Holden, J.H.W. and J.T. Williams. 1984. Crop genetic resources: Conservation and evaluation. George Allen and Unwin, London.

Huff, D.R., R. Peakall, and P.E. Smouse. 1993. RAPD variation within and among populations of outcrossing buffalograss [Buchlöe dactyloides (Nutt.) Engelm.]. Theor. Appl. Genet. 86:927934.

James, F.C. and C.E. McCulloch. 1990. Multivariate analysis in ecology and systematics: Panacea or Pandora's box? Annu. Rev. Ecol. Syst. 21:129-166.

Jeffreys, A., V. Wilson, and S.L. Thein. 1985. Hypervariable "minisatellite" regions in human DNA. Nature (London) 314:67-73.

Kaemmer, D.R., Afza, F. Weising, G. Kahl, and J. 
Novak. 1992. Oligonucleotide and amplification fingerprinting of wild species and cultivars of banana (Musa spp.). Biotechnology 10:1030 1035.

Kato Y., T.A. 1984. Chromosome morphology and the origin of maize and its races. Evol. Biol. 17:219-253.

Keefe, P.D. and S.R. Draper. 1988. An automated machine vision system for the morphometry of new cultivars and genebank accessions. Plant Var. Seeds 1:1-11.

Kephart, S.R. 1990. Starch gel electrophoresis of plant isozymes: A comparative analysis of techniques. Amer. J. Bot. 77:693-712.

Kimura, M. 1983. The neutral theory of molecular evolution. Cambridge Univ. Press, Cambridge, U.K.

Klein, R.E., S.D. Wyatt, and W.J. Kaiser. 1990. Effect of diseased plant elimination on genetic diversity and bean common mosaic virus incidence in Phaseolus vulgaris germplasm collections. Plant. Dis. 74:911-913.

Knott, D.R. and J. Dvorak. 1976. Alien germplasm as a source of resistance to diseases. Annu. Rev. Plant Pathol. 14:211-235.

Koehn, R.K. and T.J. Hilbish. 1987. The adaptive importance of genetic variation. Amer. Sci. 75:134-141.

Kresovich, S. and J. McFerson. 1992. Assessment and management of plant genetic diversity: Considerations of intra- and interspecific variation. Field Crops Res. 29:185-204.

Kresovich, S., J.G.K. Williams, J.R. McFerson, E.J. Routman, and B.A. Schaal. 1992. Characterization of genetic identities and relationships of Brassica oleracea L. via a random amplified polymorphic DNA assay. Theor. Appl. Genet. 85:190-196.

Kulakow, P.A., H. Hauptli, and S.K. Jain. 1985 Genetics of grain amaranths. I. Mendelian analysis of six color characteristics. J. Hered. 76:2730 .

Kwoh, D.Y. and T.J. Kwoh. 1990. Target amplification systems in nucleic acid-based diagnostic approaches. Amer. Biotechnol. Lab. 8(13):1425.

Leleji, O.I. 1973. Apparent preference by bees for different flower colours in cowpeas [Vigna sinensis (L.) Savi ex Haask.]. Euphytica 22:150 153.

Litt, M. and J.A. Luty. 1989. A hypervariable microsatellite revealed by in vitro amplification of a dinucleotide repeat within the cardiac muscle actin gene. Amer. J. Human Genet. 44:397-401.

Manganaris, A.G. and F.H. Alston. 1987. Inheritance and linkage relationships of glutamate oxaloacetate transaminase isoenzymes in apple I. The gene Got-1, a marker for the $S$ incompatibility locus. Theor. Appl. Genet. 74:154-161.

Manly, B.F.J. 1986. Multivariate statistical methods: A primer. Chapman and Hall, London.

Martin, G.B., J.G.K. Williams, and S.D. Tanksley. 1991. Rapid identification of markers linked to Pseudomonas resistance gene in tomato by using random primers and near-iosgenic lines. Proc. Natl. Acad. Sci. USA 88:2336-2340.

McClintock, B., T.A. Kato Y., and A. Blumenschein. 1981. Chromosome constitution of races of maize. Colegio de Postgraduados, Chapingo, Mexico.

Miller, J.C. and S.D. Tanksley. 1990. RFLP analysis of phylogenetic relationships and genetic variation in the genus Lycopersicon. Theor. Appl. Genet. 80:437-448.

Mincione, A.E. Fillippone, and L.M. Monti. 1994. Construction of an image-based germplasm database for Phaseolus spp. Euphytica 75:149159.

Morgante, M. and A.M. Olivieri. 1993. PCR-ampli- fied microsatellites as markers in plant genetics. Plant J. 3:175-182.

Morrison, D.F. 1976. Multivariate statistical methods. 2nd ed. McGraw-Hill, New York.

Mullis, K., F. Faloona, S. Scharf, S. Saiki, G. Horn, and H. Erlich. 1986. Specific enzymatic amplification of DNA in vitro. Cold Spring Harbor Symp. Quantitative Biol. 51:263-273.

Murphy, R.W., J.W. Sites, D.G. Buth, and C.H. Haufler. 1990. Proteins I: Isozyme electrophoresis, p. 45-126. In: D.M. Hillis and C. Moritz (eds.). Molecular systematics. Sinauer Assoc., Sunderland, Mass.

Murray, M.G., Y. Ma, J. Romero-Severson, D.P. West, and J.H. Cramer. 1988. Restriction fragment length polymorphisms: What are they and how can breeders use them? Rpt. Annu. Corn \& Sorghum Res. Conf. 43:72-87.

Nakamura, Y., M. Leppert, P.O'Connell, R. Wolff, T. Holm, M. Culver, C. Martin, E. Fujimoto, M Hoff, E. Kumlin, and R. White. 1987. Variable number tandem repeat (VNTR) markers for human gene mapping. Science 235:1616-1622.

Nance, W.L., G.A. Tuskan, C.D. Nelson, and R.L. Doudrick. 1992. Potential applications of molecular markers for genetic analysis of hostpathogen systems in forest trees. Can. J. For. Res. 22:1036-1043

Nei, M. 1972. Genetic distance between populations. Amer. Naturalist 106:283-292.

Nei, M. 1973. Analysis of gene diversity in subdivided populations. Proc. Natl. Acad. Sci. USA 70:3321-3323.

Nei, M. 1987. Molecular evolutionary genetics. Columbia Univ. Press, New York.

Nei, M. and W. Li. 1979. Mathematical model for studying genetic variation in terms of restriction endonucleases. Proc. Natl. Acad. Sci. USA 76:5269-5273.

Nei, M. and F. Tajima. 1983. Maximum likelihood estimation of the number of nucleotide substitutions from restriction site data. Genetics 105:207217

Nyquist, W.E. 1991. Estimation of heritability and prediction of selection response in plant populations. Crit. Rev. Plant Sci. 10:235-322.

Paterson, A.H., S.D. Tanksley, and M.E. Sorrells. 1991. DNA markers in plant improvement. Adv. Agron. 46:39-60.

Pickersgill, B. 1971. Relationships between weedy and cultivated forms in some species of chili peppers (genus Capsicum). Evolution 25:683691.

Pickersgill, B. 1981. Biosystematics of crop-weed complexes. Kulturpflanze 29:377-388.

Plucknett, D.L., N.J.H. Smith, J.T. Williams, and N. Murthi Anishetty. 1987. Gene banks and the world's food. Princeton Univ. Press, Princeton, N.J.

Ragot, M. and D.A. Hoisington. 1990. Molecular markers for plant breeding: Comparisons of RFLP and RAPD genotyping costs. Theor. Appl Genet. 86:975-984.

Recchio-Demmin, B.E., J.R. McFerson, and S Kresovich. 1990. Genetic impact of the pea seedborne mosaic virus eradication program on the U.S.A. national Pisum collection. Pisum Nwsl. 22:46-47.

Revilla, P. and W.F. Tracy. 1995. Morphological characterization and classification of open-pollinated sweet corn varieties. J. Amer. Soc. Hort. Sci. 120:112-118.

Rick, C.M. 1988. Tomato-like nightshades: Affinities, autoecology, and breeders' opportunities. Econ. Bot. 42:145-154

Rick, C.M. and J.F. Fobes. 1974. Association of an allozyme with nematode resistance. Rpt. Tomato Genet. Coop. 24:25

Rogers, J.S. 1972. Measures of genetic similarity and genetic distance. Studies in Genetics VII. Univ. of Texas Publications 7213:145-153.

Roos, E.E. 1984a. Genetic shifts in mixed bean populations. I. Storage effects. Crop Sci. 24:240 244.

Roos, E.E. 1984b. Genetic shifts in mixed bean populations. II. Effects of regeneration. Crop Sci. 24:711-715.

Rubino, D.B. and D.W. Davis. 1991. Maintenance of tropical isozyme alleles during random mating in a semiexotic maize composite. J. Hered. 82:423-425

Sánchez G., J.J., M.M. Goodman, and J.O. Rawlings. 1993. Appropriate characters for racial classification in maize. Econ. Bot. 47:44-59.

Schoen, D.J. and A.H.D. Brown. 1993. Conservation of allelic richness in wild relatives is aided by assessment of genetic markers. Proc. Natl Acad. Sci. USA 90:10623-10627.

Senior, M.L. and M. Heun. 1993. Mapping maize microsatellites and polymerase chain reaction confirmation of the targeted repeats using a CT primer. Genome 36:884-889.

Simmonds, N.W. (ed.). 1976. Evolution of crop plants. Longmans, London.

Simmonds, N.W. 1993. Introgression and incorporation strategies for the use of crop genetic resources. Biol. Rev. 68:539-562.

Simon, C. and J. Archie. 1985. An empirical demonstration of the lability of heterozygosity estimates. Evolution 39:463-467.

Simpson, M.J.A. and L.A. Withers. 1986. Characterization of plant genetic resources using isozyme electrophoresis: A guide to the literature. IBPGR, Rome.

Smith, J.S.C. 1989. Gene markers and their uses in the conservation, evaluation, and utilization of genetic resources of maize (Zea mays L.), p. 125-138. In: H.T. Stalker and C. Chapman (eds.). Scientific management of germplasm: Characterization, evaluation, and enhancement IBPGR training courses: Lecture series 2. Dept of Crop Science, North Carolina State Univ. Raleigh, and IBPGR, Rome.

Smith, J.S.C. 1992. Plant breeders' rights in the USA: Changing approaches and appropriate technologies in support of germplasm enhancement. Plant Var. Seeds 5:183-189.

Smith, J.S.C. and O.S. Smith. 1992. Fingerprinting crop varieties. Adv. Agron. 47:85-140.

Smith, O.S., J.S.C. Smith, S.L. Bowen, and R.A Tenborg. 1991. Numbers of RFLP probes necessary to show associations between lines. Maize Genet. Coop. Nwsl. 65:66.

Sneath, P. and R.R. Sokal. 1973. Numerical taxonomy. 2nd ed. W.H. Freeman, San Francisco.

Sokal, R.R. 1986. Phenetic taxonomy: Theory and methods. Annu. Rev. Ecol. Syst. 17:423-442.

Soller, M. and J.S. Beckmann. 1988. Genomic genetics and the utilization for breeding purposes of genetic variatiion between populations, $\mathrm{p}$ 161-168. In: B.S. Weir, E.J. Eisen, M.M. Goodman, and G. Namkoong (eds.). Proceedings of the second international conference on quantitative genetics. Sinauer Assoc., Sunderland, Mass.

Soulé, M. and O. Frankel. 1981. Conservation and evolution. Cambridge Univ. Press, Cambridge, U.K

Stalker, H.T. 1980. Utilization of wild species for crop improvement. Adv. Agron. 33:111-147.

Stuessy, T. 1990. Plant taxonomy. Columbia Univ. Press, New York.

Surrs, L.C.J.M. 1986. Routine large-scale electrophoresis for plant breeding. An example with $\mathrm{F}_{1}$ seeds of brussels sprouts (Brassica oleracea var. gemmifera). Euphytica 36:147-151.

Swofford, D.L. and G.J. Olsen. 1990. Phylogeny reconstruction, p. 411-501. In: D.M Hillis and 
C. Moritz (eds.). Molecular systematics. Sinauer Assoc., Sunderland, Mass.

Tanksley, S.D. and R.A. Jones. 1981. Application of alcohol dehydrogenase allozymes in testing the genetic purity of $F_{1}$ hybrids of tomato. HortScience 16:179-181.

Tanksley, S.D. and T.J. Orton (eds.). 1983a. Isozymes in plant genetic and breeding. vol. 1A. (Developments in plant genetics and breeding, 1). Elsevier, Amsterdam, The Netherlands.

Tanksley, S.D. and T.J. Orton (eds.). 1983b. Isozymes in plant genetic and breeding. vol. 1B. (Developments in plant genetics and breeding, 1). Elsevier, Amsterdam, The Netherlands

Tanksley, S.D., N.D. Young, A.H. Paterson, and M.W. Bonierbale. 1989. RFLP mapping in plant breeding: New tools for an old science. Bio/Technology 7:257-264.

Thomas, M.R., S. Matsumoto, P.C. Cain, and N.S. Scott. 1993. Repetitive DNA of grapevine: Classes present and sequences suitable for cultivar identification. Theor. Appl. Genet. 86:173180

Thomas, M.R. and N.S. Scott. 1994. Sequencetagged site markers for microsatellites: Simplified techniques for rapidly obtaining flanking sequences. Plant Mol. Biol. Rptr. 12:58-61.

Torres, A.M., R.K. Soost, and T. Mau-Lastovicka. 1982. Citrus isozymes: Genetics and distinguishing nucellar from zygotic seedlings. J. Hered. 73:335-339.
Walters, T.W. and D.S. Decker-Walters. 1993. Systematics of the endangered Okeechobee gourd (Cucurbita okeechobeensis: Cucurbitaceae). Syst. Bot. 18:175-187.

Walton, M. 1990. Application of RFLP technology to applied plant breeding, p. 335-346. In: A.B. Bennett and S.D. O'Neil (eds.). Horticultural biotechnology: Proc. Hort. Biotechnol. Symp. held at the Univ. of California, Davis, 21-23 Aug. 1989. Wiley-Liss, New York.

Wang, Z., J.L. Weber, G. Zhang, and S.D. Tanksley. 1994. Survey of plant short tandem repeats. Theor. Appl. Genet. 88:1-6.

Weeden, N.F. and J.F. Wendel 1989. Genetics of plant isozymes, p. 46-72. In: D. Soltis and P. Soltis (eds.). Isozymes in plant biology. Dioscorides Press, Portland, Ore.

Weir, B.S. 1990. Genetic data analysis. Sinauer Assoc., Sunderland, Mass.

Welsh, J. and M. McClelland. 1990. Fingerprinting genomes using PCR with arbitrary primers. Nucleic Acids Res. 18:7213-7218.

Wendel, J.F. and N.F. Weeden. 1989. Visualization and interpretation of plant isozymes, p. 5-45. In: D. Soltis and P. Soltis (eds.). Isozymes in plant biology. Dioscorides Press, Portland, Ore.

Widrlechner, M.P. and N.P. Senechal. 1992. Relationships between nectar production and honey bee preference. Bee World 73:119-127.

Williams, C.E. and D.A. St. Clair. 1993. Phenetic relationships and levels of variability detected by restriction fragment length polymorphisms and random amplified DNA analysis of cultivated and wild accessions of Lycopersicon esculentum. Genome 36:619-630.

Williams, J.G.K., M.K. Hanafey, J.A. Rafalski, and S.V. Tingey. 1993. Genetic analysis using random amplified polymorphic DNA markers. Methods in Enzymology 218:704-740.

Williams, J.G.K., A.R. Kubelik, K.J. Livak, J.A. Rafalski, and S.V. Tingey. 1990. DNA polymorphisms amplified by arbitrary primers are useful as genetic markers. Nucleic Acids Res. 18:6531-6535.

Wilson, R.L. 1989. Minimizing extraneous transfer of sunflower pollen by honey bees (Hymenoptera: Apidae) in field cages. J. Kan. Entomol. Soc. 62:387-391.

Wolfe, K.H., W.H. Li, and P.M. Sharp. 1987. Rates of nucleotide substitution vary greatly among plant mitochondrial, chloroplast, and nuclear DNAs. Proc. Natl. Acad. Sci. USA 84:90549058.

Wright, S. 1978. Variability within and among natural populations. vol. 4. (Evolution and the genetics of populations). Univ. of Chicago Press, Chicago.

Zabeau, M. and P. Vos. 1993. Selective restriction fragment amplification: A general method for DNA fingerprinting. European Patent Application 0534858 A1, European Patent Office, Paris.

PULL DYNAMAX ad FROM p. 1328 of OCT. 1995 ISSUE

\author{
DROP KEYLINE
}

